\title{
Acquisition of new genes by oral Neisseria
}

\author{
CATHERINE ISON, AA GLYNN, ${ }^{*}$ SHOSHANA BASCOMB \\ From the Wright-Fleming Institute, St Mary's Hospital Medical School, London W2, and the *Central Public \\ Health Laboratory, Colindale, London NW9
}

SUMMARY It is suggested that part of the increased pharyngeal carriage of meningococci reported in patients with gonorrhoea is due to misidentification of gonococci which have been transformed to maltose fermenters by DNA from normal throat flora. The distribution of specific aminopeptidases in strains of gonococci, meningococci isolated from the throat and meningococci from systemic infections is consistent with this view. Gonococci oxidising maltose and gonococci with $\gamma$-L-glutamyl aminopeptidase activity, both factors regarded as typical of Neisseria meningitidis, can be produced in vitro by transformation with DNA from $N$ lactamica and $N$ meningitidis. The clinical and theoretical implications of such changes are discussed.

The unduly high frequency of meningococcal carriage in patients with gonorrhoea noticed by Willcox et al $^{1}$ was confirmed by Rufli ${ }^{2}$ and Young et al, ${ }^{3}$ but not by Noble et al. ${ }^{4}$ Differences in reported results may be related to the type of population studied. Most of the patients studied in the sexually transmitted disease (STD) clinic at St Mary's were male homosexuals with a recent history of oral sexual intercourse. Turgeon $e \mathrm{al}^{5}$ reported meningococcal carriage in $41 \%$ of homosexual men compared with $17 \%$ in heterosexual men and $11 \%$ in women. Two explanations given for these findings are, promiscuity favouring the spread of both meningococci and gonococci and undue susceptibility of some individuals to both these species of Neisseria. Evidence for a third possibility is given below.

In most clinical laboratories the definitive distinction between Neisseria gonorrhoeae and Neisseria meningitidis is the,ability of the latter to oxidise maltose as well as glucose. It is conceivable that DNA from normal mouth flora may transform some strains of $N$ gonorrhoeae so that they acquire the ability to oxidise maltose and are subsequently misidentified as $N$ meningitidis. ${ }^{6} 7$

Neisseria gonorrhoeae and $N$ meningitidis also differ in their aminopeptidase (AP) profiles, ${ }^{89}$ in asparaginase ${ }^{10}$ and glutaminase activity and in sensitivity to oleic acid. ${ }^{11}$ These criteria have been used to examine the relation of throat meningococci to systemic meningococci and gonococci. Lastly, the hypothesis has been tested by transformation experiments in vitro using DNA from Neisseria spp found

Accepted for publication 25 February 1982 in the throat with a proline auxotrophic strain of $N$ gonorrhoeae as the recipient.

\section{Material and methods}

STRAINS OF BACTERIA

A bank of strains was established as described below. Not all the tests were done on all strains as some died out during the period of the experiments.

\section{Neisseria gonorrhoeae}

Fifty-two strains were all isolated in the diagnostic laboratory from the urethra, rectum, or cervix of patients attending the sexually transmitted diseases (STD) clinic.

\section{Neisseria meningitidis}

Fifty strains, all isolated from the blood or cerebrospinal fluid of patients with systemic infections, were provided by Dr AG Taylor (Central Public Health Laboratory, Colindale). A further 120 strains were isolated from the throats of male patients recently attending the STD clinic with a history of oral sexual intercourse.

\section{CULTURE AND IDENTIFICATION}

Strains were initially isolated on GC agar base $+1 \%$ Isovitalex made selective by the addition of vancomycin, colistin, trimethoprim and nystatin, ${ }^{12}$ and incubated at $36^{\circ} \mathrm{C}$ in $7 \% \mathrm{CO}_{2}$. All further subcultures were made on the same medium without antibiotics and were all oxidase positive, Gram-negative cocci. Strains were identified as $N$ gonorrhoeae if they produced acid from the oxidation of glucose only. Strains 
were identified as $N$ meningitidis if they produced acid from glucose and maltose, but not from sucrose and lactose. After identification each isolate was suspended in $10 \%$ glycerol and stored in ampoules in liquid nitrogen. ${ }^{13}$

\section{QUANTITATIVE AMINOPEPTIDASE ASSAY}

Each strain was grown overnight on GC agar $+1 \%$ Isovitalex and a heavy suspension made in saline. The absorbance was adjusted to $1.0(\lambda=540 \mathrm{~nm})$ for the glutamyl aminopeptidase assay and to 5.0 for the specific hydroxyproline aminopeptidase assay. The protein concentration of the adjusted suspensions were estimated by the method of Lowry et al. ${ }^{14}$

Assays were done in duplicate in flat-bottomed microtitre plates (Dynatech). Suspension $(50 \mu \mathrm{l})$ was tested with specific substrate $(50 \mu \mathrm{l})$ and a buffer control. After three hours incubation in moist conditions at $37^{\circ} \mathrm{C}$, the colour was developed by the addition of $50 \mu \mathrm{l}$ each of $0.08 \%$ sodium nitrite, $0.4 \mathrm{~N}$ hydrochloric acid, $2 \%$ ammonium sulphamate and $1.6 \%$ naphthylethylene diamine (in methanol) in that order and the absorbance measured immediately. Two specific substrates were used, $1 \mathrm{mmol} \mathrm{L-} \gamma$-glutamyl-4-nitroanilide (BDH) in $0.2 M$ TRIS pH $7 \cdot 6$, and L-4-hydroxyprolyl- $\beta$-naphthylamide (KochLight) $0.2 M$ TRIS pH $7 \cdot 2$.

The absorbance was read at $550 \mathrm{~nm}$ using a Titertek Multiskan (Flow Labs), and compared to the appropriate standard curve using either $p$ nitroaniline (BDH), or $\beta$-naphthylamine (LAP calibration solution, Sigma) $0-250 \mathrm{nmol} / \mathrm{ml}$. The specific enzyme activity was expressed per $\mathrm{mg}$ protein of the original suspension.

\section{ESTIMATION OF ASPARAGINASE AND \\ GLUTAMINASE}

Bacterial suspensions were prepared as above. The substrates used were $50 \mu \mathrm{l}$ of $5 \mathrm{mmol} \mathrm{L}$-asparagine or $5 \mathrm{mmol}$ L-glutamine in $0.05 \mathrm{M}$ borate buffer $\mathrm{pH} 8 \cdot 0$. After two hours incubation at $37^{\circ} \mathrm{C}$, the ammonia released was measured using Nessler's reagent. ${ }^{15}$ The enzyme activity was expressed as $\mathrm{mmol} \mathrm{NH}_{3}$ released per mg protein; ammonium chloride, 0-30 mmol was used for the standard curve.

\section{SENSITIVITY TO OLEIC ACID}

Agar plates were prepared containing GC base agar $+1 \%$ Isovitalex with the addition of Dubos broth base with and without $0.02 \%(\mathrm{wt} / \mathrm{vol})$ oleic acid (Gibco Diagnostics). Bacterial suspensions were adjusted to absorbance $1.0(\lambda=540 \mathrm{~nm})$ and also diluted $1 / 100$. They were inoculated on to both media using a multipoint inoculator (Denley). After incubation at $36^{\circ} \mathrm{C}$ for $48 \mathrm{~h}$ in $7 \% \mathrm{CO}_{2}$, the presence or absence of growth was assessed.

\section{TRANSFORMATION}

DNA isolated from strains of $N$ meningitidis and $N$ lactamica (NCTC 10617) was used in transformation experiments using the rapid method described by Janik et al. ${ }^{18}$ The recipient was a strain of $N$ gonorrhoeae (colony type 1) which requires proline for growth. Pro ${ }^{+}$transformants were detected on chemically defined media. ${ }^{17}$ Pro $^{+}$colonies were transferred to maltose-containing plates ${ }^{18}$ using the replica technique with velvet pads. Some transformants were tested for aminopeptidase activity by the quantitative method described earlier.

\section{Results}

\section{AMINOPEPTIDASE ACTIVITY}

Specific $\gamma$-L-glutamyl and L-hydroxyproline aminopeptidase activity was measured quantitatively in all strains. The significance of differences between means was estimated by student's $t$ test.

The mean specific $\gamma$-L-glutamyl AP activity of the $N$ gonorrhoeae strains is one tenth that of both groups of $N$ meningitidis ( $\mathrm{p}<0.001$ ). Meningococci isolated from the throat have significantly less activity than systemic meningococci $(\mathrm{p}<0.001)$.

The mean specific L-hydroxyproline AP is significantly higher in $N$ gonorrhoeae, tenfold that of the meningococci taken as a whole $(\mathrm{p}<0 \cdot 001)$. Withino the meningococci activity was significantly higher in the throat than in the systemic strains $(\mathrm{p}<0.02)$.

The relation of the two specific aminopeptidases in individual strains can be seen in the Figure $(a, b, c)$. The difference between $N$ gonorrhoeae and systemic meningococci is clear. The throat meningococci are a more heterogeneous group. They have a lower mean glutamyl and higher mean hydroxyproline AP activity than the systemic strains. If the throat strains are divided into those with and without hydroxyproline AP activity, the mean glutamyl AP activity is lower in those with hydroxyproline AP, but the difference is not statistically significant.

\section{ASPARAGINASE AND GLUTAMINASE}

The mean values for each group of strains tested are shown in Table 1. Neisseria gonorrhoeae differ significantly from $N$ meningitidis, having one-third of the asparaginase and one tenth of the glutaminase activity. However, the two groups of meningococci do not differ significantly from each other.

\section{OLEIC ACID SENSITIVITY}

Neisseria gonorrhoeae are significantly more sensitive to oleic acid than $N$ meningitidis (Table 2). Although throat meningococci appear more sensitive than systemic strains, the difference is not statistically significant. 

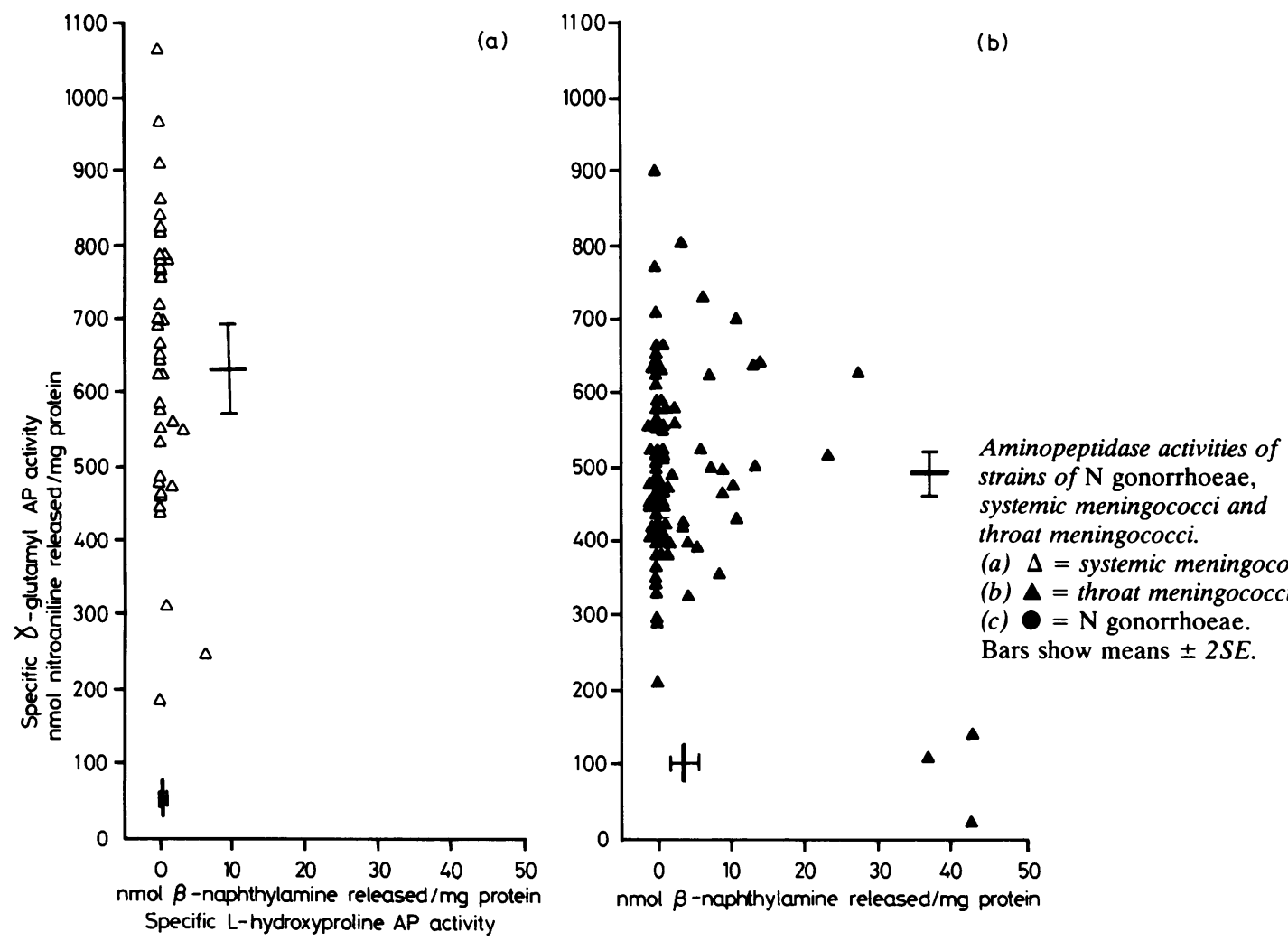
throat meningococci.

(a) $\Delta=$ systemic meningococci.

(b) $\mathbf{\Delta}=$ throat meningococci.

(c) $\mathbf{0}$ N gonorrhoeae.

Bars show means $\pm 2 S E$.

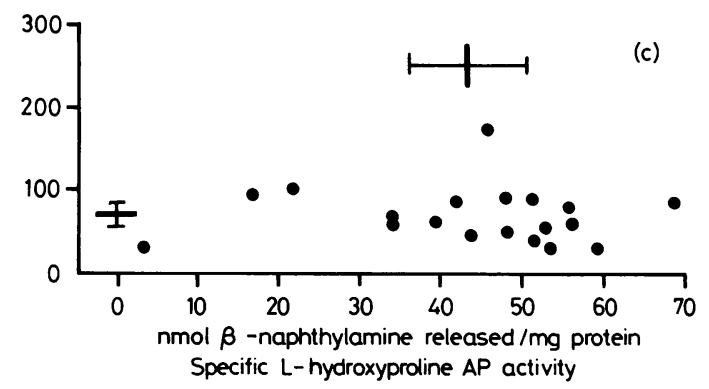

Table 1 Asparaginase and glutaminase activity in Neisseria gonorrhoeae and $\mathrm{N}$ meningitidis

\begin{tabular}{|c|c|c|c|c|}
\hline & \multirow[t]{2}{*}{ No tested } & \multicolumn{3}{|c|}{$\begin{array}{l}\text { mmol } N_{4} H_{4} \text { released } / m g \text { protein } \\
\text { Substrate }\end{array}$} \\
\hline & & $\begin{array}{l}\text { L-asparagine } \\
\text { Mean }(S E)\end{array}$ & $\begin{array}{l}\text { L-glutamine } \\
\text { Mean }(S E)\end{array}$ & Asp:glut ratio \\
\hline $\begin{array}{l}{ }^{*}+N \text { gonorrhoeae } \\
{ }^{*} \neq N \text { meningitidis (throat) } \\
\dagger \neq N \text { meningitidis (blood/CSF) }\end{array}$ & $\begin{array}{l}52 \\
80 \\
42\end{array}$ & $\begin{array}{l}1.99(0 \cdot 2) \\
6 \cdot 29(0 \cdot 22) \\
5 \cdot 52(0 \cdot 23)\end{array}$ & $\begin{array}{l}0.29(0.04) \\
2 \cdot 33(0 \cdot 12) \\
2 \cdot 09(0.14)\end{array}$ & $\begin{array}{l}6 \cdot 9 \\
2 \cdot 7 \\
2 \cdot 6\end{array}$ \\
\hline
\end{tabular}

*tp $<0.01$ (Student's $t$ test).

¥NS (Student's $t$ test).

TRANSFORMATION

When DNA isolated from various strains of $N$ meningitidis and $N$ lactamica was used, the pro $^{+}$gene was transferred to the proline-requiring recipient in approximately 1 in every 100 colony forming units (CFU) tested. Of the pro ${ }^{+}$transformants made with meningococcal DNA and tested for glutamyl AP activity (Table 3), 13 (4\%) had gained the ability to 
make this enzyme with activities at levels equivalent to that of the donor. The ability to oxidise maltose was not detected in these transformants. This is partly a reflection of the small number tested, but it may be that the maltose and proline genes are far apart. When $N$ lactamica was used as the donor, the ability to oxidise maltose was found in $20(0.2 \%)$ of pro $^{+}$transformants tested. They had all retained the ability to oxidise glucose, and had not acquired the ability to oxidise lactose. The pro $^{+}$gene has also been transferred to $N$ gonorrhoeae using DNA from $N$ pharyngis and $E$ coli.

Table 2 Sensitivity of $\mathrm{N}$ gonorrhoeae and $\mathrm{N}$ meningitidis to oleic acid

\begin{tabular}{llll}
\hline & \multirow{2}{*}{$\begin{array}{l}\text { No } \\
\text { tested }\end{array}$} & \multicolumn{2}{c}{ \% inhibited at } \\
\cline { 3 - 4 } \cline { 3 - 4 } & & Abs $1 \cdot 0$ & Abs 0.01 \\
\hline$\dagger N$ gonorrhoeae & 25 & 80 & 96 \\
$*+N$ meningitidis (throat) & 96 & $9 \cdot 3$ & $20 \cdot 8$ \\
$*+N$ meningitidis (blood/CSF) & 46 & 6.5 & 17.4 \\
\hline
\end{tabular}

Oleic acid was used at $0.02 \% \mathrm{wt} / \mathrm{vol}$. Bacteria were plated at absorption $=1.0$ and 0.01

*NS ( $x^{2}$ test)

tp $<0.01$ ( $\chi^{2}$ test $)$.

Table 3 Phenotypic changes in transformed $\mathrm{N}$ gonorrhoeae

\begin{tabular}{|c|c|c|c|}
\hline \multirow[t]{2}{*}{ Donor DNA } & \multirow{2}{*}{$\begin{array}{l}\text { No pro }{ }^{+} \\
\text {transformants } \\
\text { tested }\end{array}$} & \multicolumn{2}{|l|}{ No positive for } \\
\hline & & $\begin{array}{l}\gamma \text {-glutamyl } A P \\
\text { activity }\end{array}$ & $\begin{array}{l}\text { Maltose } \\
\text { fermentation }\end{array}$ \\
\hline $\begin{array}{l}N \text { meningitidis } \\
N \text { lactamica }\end{array}$ & $\begin{array}{r}331 \\
8340\end{array}$ & $\begin{array}{l}13 \\
\text { NT }\end{array}$ & $\begin{array}{r}0 \\
20\end{array}$ \\
\hline
\end{tabular}

\section{Discussion}

The aminopeptidase results confirm the clear distinction between $N$ gonorrhoeae and $N$ meningitidis described previously; ${ }^{8}{ }^{9} \quad$ gonorrhoeae showing hydroxyproline AP activity only and meningococci showing glutamyl AP activity only. However, the throat meningococci can be divided into three populations, $66 \%$ of strains giving the typical meningococcal pattern, $30 \%$ which also had some hydroxyproline AP, and lastly three strains with no glutamyl AP but hydroxyproline AP at levels similar to those of gonococci.

The group showing both enzyme activities would be consistent with gonococci that have gained DNA derived from normal mouth flora and consequently gained glutamyl AP and the ability to oxidise maltose, while retaining hydroxyproline AP. However, particularly in view of their relatively low hydroxyproline AP activity, they could be meningococci which had gained some DNA from gonococci. The possibility that hydroxyproline AP may be repressed when glutamyl AP is acquired, was not confirmed by quantitative estimations on the transformants.

The three strains with no glutamyl AP could be gonococci which had gained a maltose-oxidising enzyme. The possibility that they are meningococci which have gained hydroxyproline AP and lost glutamyl AP seems less likely. Moreover, there is no evidence to suggest that throat rather than systemic strains should lose DNA, whereas gonococci are known to be highly competent to accept DNA. ${ }^{7}$ Changes in phenotype are probably not limited to the markers we have used and this could explain differences in auxotype between strains of gonococci isolated from different sites on the same patient. ${ }^{19}$

Whatever the nature and frequency of maltosepositive Neisseria in throats of STD patients, maltose oxidation alone appears to be an inadequate method of identification of meningococci. Previously some $80 \%$ of sulphadiazine-resistant meningococci were found to be maltose-negative. ${ }^{20}$ Reports of the greater sensitivity of gonococci to oleic acid ${ }^{11}$ need to be interpreted with caution as the method is difficult to quantify and some strains are anomalous. A combination of tests such as aminopeptidases and carbohydrate fermentation may well be required to give the best differentiation.

DNA hybridisation experiments have shown that meningococci and gonococci are homologous fop about $80 \%$ of their genome. ${ }^{21}$ It is therefore not surprising that they have so many properties in common. Recent experience of plasmid spread within and between species has led to a renewed appreciation of bacterial variability. We should give more attention to the possibilities of chromosomal gene exchange. These results give preliminary evidence for such exchange between $N$ gonorrhoeae and normal mouth flora, though it probably occurs in only a small number of strains. Nevertheless gene exchange may be another factor besides increased acquisition and undue susceptibility contributing to the increased prevalence of meningococcal carriage by STD patients. Further investigations on DNA hybridisation and on the presence of plasmids are in progress.

There are frequent references in published reports to the isolation of either meningococci or gonococci from sites and under circumstances regarded as typical of the other-for example, gonococcal meningitis and meningococcal urethritis ${ }^{22-24}$ and these would support the theory of genetic interchange leading to misdiagnosis. There does, however, exist the possibility that meningococci and gonococci belong to one species adapting to different environments.

We thank Dr AG Taylor for strains of $N$ meningitidis, Dr D Danielsson for the special sero typing, Miss G 
Hadfield for helpful advice and Mrs C Bellinger for technical assistance.

The work was supported by a programme grant from the Medical Research Council.

\section{References}

1 Willcox RR, Spencer RC, Ison C. Which Neisseria? BrJ Vener Dis 1977;53:394-7.

2 Rufli T. Letter Br J Vener Dis 1978;54:352-5.

3 Young H, Harris AB, Robertson DHH. Individual susceptibility to neisserial infection? Br J Vener Dis 1979;55:188-90.

- Noble RC, Cooper RM, Miller BR. Pharyngeal colonisation by Neisseria gonorrhoeae and Neisseria meningitidis in black and white patients attending a venereal disease clinic. BrJ Vener Dis 1979;55:14-19.

s Turgeon PL, Allard R, Robert J, Turgeon F. Isolation of gonococci and meningococci in a high-risk population. Abstracts of the Annual Meeting of the American Society for Microbiology, 1981:310.

- Ison C, Bellinger C, Glynn AA. Neisserial carriage in a STD clinic. In: Danielsson D, Normark S, eds Genetics and immunobiology of pathogenic neisseria. Norlands-Tryck: Umea AB. 1980: 185-8.

7 Sparling PF, Biswas GD, Sox TE. Transformation of the Gonococcus. In: Roberts RB, ed. The gonococcus. New York: Jon Wiley. 1977:156-76.

- D'Amato RF, Eriquez LA, Tomfohrde KM, Singerman E. Rapid identification of Neisseria gonorrhoeae and Neisseria meningitidis by using enzymatic profiles. J Clin Microbiol 1978;7:77-81.

- Watson RR, Perrine S. Aminopeptidase profiles from cells of Neisseria gonorrhoeae, $N$ sicca, $N$ meningitidis, $N$ flava and Branhamella catarrhalis. In: Brooks GF, Gotschlich EC, Holmes KK, Sawyer WD, Young FE, eds. Immunobiology of Neisseria gonorrhoeae. Washington, DC: American Society for Microbiology, 1978:35-9.

${ }^{10}$ Chen KCS, Buchanan TM. Gonococcal hydrolases: gonocosin, aminopeptidase-P, proline iminopeptidase, and asparaginase. In: Brooks GF, Gotschlich EC, Holmes KK, Sawyer WD, Young FE, eds. Immunobiology of Neisseria gonorrhoeae. Washington DC: American Society for Microbiology, 1978:30-4.
1 Diena BB, Wallace R, Kenny CP, Greenberg L. Dubos oleic agar medium in the differentiation of meningococci and gonococci. Appl Microbiol 1970;19:1025.

12 Philips I. Humphrey D. Middleton A, Nicol CS. Diagnosis of gonorrhoeae by culture on a selective medium containing vancamycin, colistin, nystatin and trimethoprim (VCNT). Br J Vener Dis 1972;48:287-92.

13 Ward ME, Watt PJ. The preservation of gonococci in liquid nitrogen. J Clin Pathol 1971;24:122-3.

14 Lowry OH, Rosenbrough NJ, Farr AL, Randall RJ. Protein measurement with the Folin-phenol reagent. J Biol Chem 1951;193:265-75.

${ }^{15}$ Bascomb S, Grantham CA. Application of automated assay of asparaginase and other ammonia-releasing enzymes to the identification of bacteria. In: Board RG, Lovelock DW, eds. Some methods for microbiological assay. London: Academic Press, 1975:29-63.

16 Janik A, Juni E, Heym GA. Genetic transformation as a tool for detection of Neisseria gonorrhoeae. J Clin Microbiol 1976;4:71-81.

${ }^{17}$ Catlin BW. Nutritional profiles of Neisseria gonorrhoeae, Neisseria meningitidis and Neisseria lactamica in chemically defined media and the use of growth requirements for gonococcal typing. $J$ Infect Dis 1973;128:178-94.

${ }^{18}$ Flynn J, Waitkins SA. A serum-free medium for testing fermentation reactions in Neisseria gonorrhoeae. J Clin Pathol 1972;25:525-7.

19 Sandström E, Moberg I. Mixed infection as a model for gonococcal adaptation in vivo. In: Danielsson D, Normark S, eds. Genetics and immunobiology of pathogenic Neisseria. Norlands-Tryck: Umea AB 283-87.

${ }^{20}$ Kingsbury DT. Relationship between sulfadiazine resistance and the failure to ferment maltose in Neisseria meningitidis. $J$ Bacteriol 1967;94:557-61.

${ }^{21}$ Kingsbury DT. Deoxyribonucleic acid and homologies among species of the genus Neisseria. $J$ Bacteriol 1967;94:870.

22 Taubin HL, Landsberg L. Gonococcal meningitis. $N$ Engl J Med $1971 ; 285: 504-5$.

2 Keys TF, Hecht RH, Chow AW. Endocervical Neisseria meningitidis with meningococcemia. N Engl J Med 1971;285:505-6.

"Feldman HA. Meningococcus and gonococcus: never the twain . . well, hardly ever. $N$ Engl J Med 1971;285:518-20.

Requests for reprints to: Mrs Catherine Ison, WrightFleming Institute, St Mary's Hospital Medical School, London W2, England. 